\title{
A DECISION-MAKING FRAMEWORK FOR EFFECTIVE MAINTENANCE MANAGEMENT USING LIFE CYCLE COSTING (LCC) IN A ROLLING STOCK ENVIRONMENT
}

\author{
C.J. Fourie ${ }^{1 *} \&$ T.G. Tendayi ${ }^{1}$
}

\section{ARTICLE INFO}

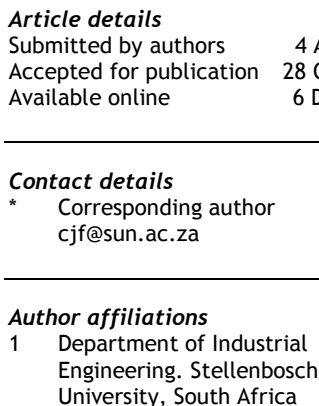

http://dx.doi.org/10.7166/27-4-1526

\section{ABSTRACT}

In this paper, a life cycle costing (LCC) framework for effective maintenance management is investigated and developed for use in a railway rolling stock environment. The framework consists of combining typical mission-critical components together with their failure and maintenance history. All costs related to the operation and maintenance of these components throughout their life cycle are also determined. The next step involves considering different scenarios under which the components can be used in relation to operations, maintenance, and replacements. The decision about which scenario to take is based on the one with the most favourable net present value after life cycle costing is performed over a specified period of time. A typical railway rolling-stock maintenance organisation in South Africa was used to highlight the practical implications of such a framework and how the company could make informed and appropriate decisions. The conclusion of this study is that such a framework is useful, and that it can be used as a basis for estimating LCC across a spectrum of critical assets found in the rolling stock environment.

\section{OPSOMMING}

In hierdie artikel is 'n lewenssikluskoste raamwerk ondersoek en ontwikkel om instandhoudingsbestuur in 'n spoorweg rollende materiaal omgewing te verbeter. Die raamwerk bestaan uit ' $n$ kombinasie van tipiese missie-kritiese komponente saam met hulle falings- en instandhoudingsgeskiedenis. Alle koste verbonde aan die bedryf en instandhouding van hierdie komponente gedurende hulle lewenssiklus is ook bepaal. Deur verskillende bedryfscenario's se lewenssikluskoste te vergelyk in terme van netto huidige waardes, kan 'n besluit oor die beste scenario geneem word. 'n SuidAfrikaanse gevallestudie is gebruik om die waarde van hierdie raamwerk te illustreer. Resultate toon dat die raamwerk wel bruikbaar is oor 'n wye spektrum van scenario's.

Having a life cycle framework in place to support the reliability, availability, maintainability, and safety of all mission-critical assets has become an integral part of decision-making in the railway environment. Maintenance management has also been described by Takata, Kirnura, van Houten, Westkamper, Shpitalni, and Ceglarek [1] as an essential way to ensure that life cycle management is achieved. Having effective maintenance management techniques in place during the operational phase of the life cycle of a product or system can make the difference between profit and loss for an organisation. This becomes even more vital as the condition of the product or system deteriorates with age. This paper acknowledges the important role that maintenance plays in the life of a product or system, and incorporates it into the traditional economic life cycle costing approach with an emphasis on the cost of ownership and the effective maintenance and replacement strategies that influence it. As a follow-up to work done by Tendayi and Fourie [2], this paper addresses the issue of uncertainty in life cycle costing - an aspect that the earlier paper did not address. 
The rest of the paper is organised as follows: the literature about LCC and the financial calculations that are involved is discussed in Section 2. LCC and its application in the railway environment are then discussed in Section 3. The relationship between LCC, RAMS (reliability, availability, maintainability, safety) and maintenance is then investigated in Section 4. In Section 5, a framework that incorporates maintenance management principles and LCC is developed and applied in a case study in the rolling stock environment. A discussion then follows in Section 6, and the paper concludes in Section 7.

\section{LIFE CYCLE COSTING}

Life cycle costing (LCC) is a major requirement of life cycle management. It refers to the technique used to "provide increased visibility of the total costs of doing business" [3]. Life cycle costs consider the cost estimates from inception to the disposal of either equipment or projects as determined by an analytical study, and an estimate of total costs experienced during the life of the equipment or projects [4]. This analytical study of life cycle costs is commonly referred to as 'life cycle cost analysis', and has been used mostly to evaluate building design alternatives and other capital investment decisions. It takes a much longer-term view than other economic analysis methods, such as the payback method, which is more concerned about getting return on investment in the shortest possible time [5]. Life cycle costs can sometimes be referred to as 'the total cost of ownership', a concept that involves identifying all future costs and reducing them to their present value using discounting techniques. These discounting techniques help to assess the value of products or product options before the investment is actually made [6].

\subsection{Discounting and present value calculations in LCC}

Life cycle cost analysis considers the costs that will be incurred sometime in the future, and so it is necessary to discount all costs to a specific decision point or value. The decision point or present value in question is known as 'the net present value' (NPV) and is calculated as shown below:

where:

$$
N P V=\sum_{n=0}^{T} C_{m}(1+x)^{-n}
$$

$C_{m}$ is the nominal cash flow in the $n$th year;

$n$ is the specific year in the life cycle costing period;

$x$ is the discount rate; and

$T$ is the length of time period under consideration.

Discount rates vary from organisation to organisation, and are highly dependent on the desired cost profile. It is also worth noting that high discount rates favour options with low capital cost, short life, and high recurring cost; while low discount rates have the opposite effect [6].

\subsection{Dealing with uncertainty in LCC}

Factors such as project life, discount rate, tax, etc., are not always easy to accurately determine and predict into the future. There is always a level of uncertainty associated with such predictions especially if there is insufficient information. This presents a challenge for the decision-maker, who now has to find ways to reduce this uncertainty and give more credibility to the final decision made. The literature is full of different approaches to dealing with uncertainty in LCC; these can be divided into deterministic and probabilistic approaches. The former approach changes one uncertain key value or combination of values at a time, whereas the latter considers a large number of possible outcomes, with the possibility accompanied by an associated probability. Table 1 illustrates a list of selected deterministic and probabilistic approaches used in LCC analysis. Of the many approaches available, as shown in the table, the deterministic method of sensitivity analysis was chosen for reasons that will be discussed in the next section. 
Table 1: Selected approaches to uncertainty assessment in LCC analysis [5]

\begin{tabular}{ll}
\multicolumn{1}{c}{ APPROACHES TO UNCERTAINTY ASSESSMENT } \\
\hline \multicolumn{1}{c}{ Deterministic } & Probabilistic \\
$\begin{array}{ll}\text { 1. Conservative benefit and cost } \\
\text { estimating }\end{array}$ & $\begin{array}{l}\text { 1. Input estimates using probability } \\
\text { distributions. }\end{array}$ \\
2. Breakeven analysis & $\begin{array}{l}\text { 2. Mean-variance criterion and coefficient } \\
\text { of variation }\end{array}$ \\
3. Sensitivity analysis & 3. Decision analysis \\
4. Risk-adjusted discount rate & 4. Simulation \\
5. Certainty equivalent technique & 5. Mathematical/analytical technique \\
6. Input estimates using expected values &
\end{tabular}

Sensitivity analysis measures the impact on project outcomes of changing one or more key input values about which there is uncertainty. Sensitivity analysis has several advantages that are discussed by Jun and Kim [7] as follows:

1. It shows how significant a single input variable is in determining project outcomes.

2. It recognises the uncertainty associated with the input.

3. It can be executed when there is little information, few resources, or little time to use more sophisticated techniques.

It has two main disadvantages: it gives no explicit probabilistic measure of risk exposure, and it includes no explicit treatment of risk assessments.

\section{LCC IN THE RAILWAY ENVIRONMENT}

Decision-makers in the railway environment have recently made use of the principles of life cycle costing in their capital investment decisions. In the literature, there has been a fair distribution of LCC studies covering both railway infrastructure and railway rolling stock (passenger service vehicles that operate on a railway). In these studies, LCC is found mainly in capital acquisition decisionmaking and maintenance strategy decision-making problems. A summary of some of the railway LCC literature available in the body of knowledge is presented in Table 2.

Table 2: Literature on railway LCC studies

\begin{tabular}{|l|l|l|l|}
\hline Author (s) & Year & Field & Objective of LCC \\
\hline Zoetman [8] & 2003 & $\begin{array}{l}\text { Railway } \\
\text { infrastructure }\end{array}$ & $\begin{array}{l}\text { To create a decision-support system } \\
\text { for analysing the long-term impacts of } \\
\text { design and maintenance decisions in } \\
\text { railway infrastructure. }\end{array}$ \\
\hline Patra [9] & 2007 & $\begin{array}{l}\text { Railway } \\
\text { infrastructure }\end{array}$ & $\begin{array}{l}\text { Optimisation of maintenance } \\
\text { strategies for maintenance and } \\
\text { renewal decisions. }\end{array}$ \\
\hline $\begin{array}{l}\text { Kumar et al. } \\
\text { [6] }\end{array}$ & 2004 & Rolling stock & $\begin{array}{l}\text { Prediction of cost of ownership of } \\
\text { capital assets and estimation of design } \\
\text { life of wagons. }\end{array}$ \\
\hline $\begin{array}{l}\text { Jun and Kim } \\
\text { [7] }\end{array}$ & 2007 & Rolling stock & $\begin{array}{l}\text { Estimation of life cycle costs on the } \\
\text { brake disks and pads of commercially- } \\
\text { operating subway vehicles. }\end{array}$ \\
\hline $\begin{array}{l}\text { Puig } \text { et al. } \\
\text { [10] }\end{array}$ & 2013 & Rolling stock & $\begin{array}{l}\text { To provide a framework of } \\
\text { maintenance decisions involving } \\
\text { acquisitions of passenger service } \\
\text { rolling stock. }\end{array}$ \\
\hline
\end{tabular}


Having a well-structured maintenance programme in place can help to achieve low LCC without increasing the acquisition cost [7]. The performance indicators for checking the desired objectives or targets during the operation and maintenance phase of a product or system can be given by taking reliability, availability, maintainability, and safety (RAMS) into consideration. RAMS is a qualitative and quantitative indicator of the degree to which a system or its components can be relied on to function as specified, and to be both available and safe as defined by the European Standard EN 50126-1:1999 [11], with specific application to the railway environment. The standard goes on to explain that RAMS is a characteristic of a system's long-term operation, and is achieved by the application of established engineering concepts, methods, tools, and techniques throughout the life cycle of the system. A commonly-used performance indicator in RAMS is the mean time between failure (MTBF), which addresses the 'availability' part of RAMS, as described by Kim, Chung, and Han [12], who also explain that setting RAMS targets too high can make the purchase, operations, and maintenance costs prohibitively high; but that on the other hand, setting low RAMS targets will affect the service quality of the product or system.

\section{APPLICATION OF MAINTENANCE/LCC FRAMEWORK}

\subsection{LCC framework}

The framework that is going to be used in this research is based on the premise that, to perform effective life cycle costing, the maintenance and operational costs have to be accurately identified and calculated. The objective of the framework is to determine which maintenance and operational conditions will result in the most ideal life cycle costs over a given period of time. The framework will be in the form of three alternatives or scenarios that involve either capital investment or maintenance implications in running the equipment in question. This framework uses concepts developed in a life cycle costing tutorial by Barringer and Weber [4].

In order to test the applicability of such a framework, a case study in the railway rolling stock maintenance environment was chosen. The direct current traction motors used on the standard ' $5 \mathrm{M} 2 \mathrm{~A}$ ' motor coaches, as defined by the company in question, were considered. Each motor coach contains four such traction motors fitted on to individual axles, which are in turn fitted on to two bogies. The maintenance department of the organisation currently practises a combination of routine maintenance and condition-based maintenance on all motor coaches. The former is done every eight weeks, during which the condition of mission-critical components - such as the traction motors - is also tested. If the condition of the traction motor is still good, the only work that is done on it is to renew the carbon brushes and replace the brush boxes. In the event that the condition of the traction motor has deteriorated, it will then have to go through stripping and replacing of worn-out or defective parts, such as bearings and insulation. Currently this work is mostly carried out by contractors hired by the organisation, and is classified as 'standard work'. The contractor may, on further testing, determine that more work needs to be done; this is classified as 'additional work'. This additional work includes tasks such as rewinding armatures, fitting new shafts, and refurbishing commutators. The decision to perform standard or additional work is also taken when there is an outright failure of the traction motor and it is brought into the workshop for investigation and repairs. A list of tasks carried out during standard work and additional work on the traction motor armature is shown in Table 3.

\subsection{Framework calculations and assumptions}

Table 4 shows the base-cost figures that were used in the calculations that follow. These cost figures were obtained from interviews with systems engineers dealing directly with the maintenance and day-to-day operations of the 5M2A traction motors. The 'lost gross margin' figures for delays and cancellations are based on a study conducted by Conradie [13], who investigated the cost implications of train failures. All amounts are quoted in the local currency of South African Rands ( $R$ or ZAR). 
Table 3: Standard vs additional work for $5 \mathrm{M} 2 \mathrm{~A}$ traction motor armature

\begin{tabular}{|c|l|}
\hline Standard work & Additional work \\
\hline $\begin{array}{c}\text { Strip, clean, mechanical checks, electrical } \\
\text { tests, assess }\end{array}$ & Renew PTFE ring \\
\hline$\checkmark \quad$ Megger at 5000 V & Supply and fit new shaft \\
\hline$\checkmark \quad$ Hi pot at 4500 V AC for 15 sec & Bore out old shaft \\
\hline \multicolumn{1}{|c|}{ Megger test at 5000 V } & $\begin{array}{l}\text { Repairs on shaft: Pinion end and } \\
\text { commutator end journal, shaft threads, } \\
\text { shrink ring journal }\end{array}$ \\
\hline$\checkmark \quad$ Commutator bar-to-bar test & Replace labyrinth seals - per set \\
\hline$\checkmark \quad$ Check polarity & $\begin{array}{l}\text { Replace resi-binder - commutator and } \\
\text { pinion ends }\end{array}$ \\
\hline Clean and paint armature & Commutator \\
\hline Skim, undercut, and bevel commutator & Repair commutator: front V-ring only \\
\hline Fire proof commutator & $\begin{array}{l}\text { Repair commutator: Old steel parts, } \\
\text { new copper pack, new V-rings }\end{array}$ \\
\hline Balance armature & $\begin{array}{l}\text { Repair commutator: Refurbish steel } \\
\text { parts, new copper pack, new V-rings }\end{array}$ \\
\hline Renew pinion key & $\begin{array}{l}\text { Supply and fit complete new } \\
\text { commutator }\end{array}$ \\
\hline Final test armature (tests as per item 1) & Replace core \\
\hline & Renew pinion \\
\hline
\end{tabular}

The following assumptions were made for the purpose of simplifying the calculations and illustrating the concepts involved in the model:

- Mean time between failure (MTBF) of the different components on the traction motor is uniform. The MTBF values used in the calculations are historical average values obtained from the organisation's computerised maintenance management system database.

- $\quad$ Time to perform standard maintenance work on different components on the traction motor is uniform.

- $\quad$ Time to perform additional repair work on different components on the traction motor is uniform.

- The failure of one traction motor results in the whole motor coach being forced to stop operating.

Table 4: Maintenance and operational baseline costs

\begin{tabular}{|c|c|c|c|c|}
\hline Cost breakdown & Carcass & Armature & Field coil & Interpole coil \\
\hline Maintenance crew/hr & $\mathrm{R} 673.00$ & R 673.00 & R 673.00 & R 673.00 \\
\hline Part replacement & R 80192.00 & R 146715.00 & R 69017.00 & R 63928.00 \\
\hline Part renewal & R 16297.00 & R 6326.00 & R 21444.00 & R 16481.00 \\
\hline Lost gross margin (cancellation) & R 56175.00 & R 56175.00 & R 56175.00 & R 56175.00 \\
\hline Lost gross margin (delay) & R 10000.00 & R 10000.00 & R 10000.00 & R 10000.00 \\
\hline Logistics cost/incident & R 500.00 & R 500.00 & R 500.00 & R 500.00 \\
\hline Stripping and testing & R 5171.00 & R 5171.00 & R 5171.00 & R 5171.00 \\
\hline Assembling & R 6094.00 & R 6094.00 & R 6094.00 & R 6094.00 \\
\hline
\end{tabular}

\subsection{The three alternatives}

\subsubsection{Alternative 1: Do nothing}

The first alternative considered is to keep running the traction motors as-is with the current expected failure rate and maintenance regime as described in the previous section. The cost implications of this scenario are shown in Table 5.

\subsubsection{Alternative 2: Replace traction motor}

Alternative 2 involves replacing the current traction motor with a new one. It is expected that the performance of the new traction motor, in terms of the MTBF, will significantly improve from the current one that has been in use for over 50 years. The improvement will be around 60 per cent, as 
estimated by the systems engineer interviewed. Shown in Table 6 are the expected maintenance and operational costs associated with this alternative. The requirements for preventative maintenance will not be as great because the components are newer. However, capital costs will be incurred in acquiring the new motors, together with training and installation costs.

\subsubsection{Alternative 3: Add redundant traction motor}

Alternative 3 involves having a standby/redundant traction motor in place so that, as soon as the currently operational one stops working, the standby motor kicks in. The current design of the 5M2A motor coach allows for one of the motors to 'cut out', allowing it to run with three instead of four motors. The MTBF will remain virtually the same as for the new one; although, if the motor coach remains in this 'cut-out' stage for many trips, the likelihood of failure will significantly increase. The lost gross margin due to cancellations will be eliminated, although there will be some delays experienced, as a technician would have to be called out to the site to isolate the failed traction motor. The overall MTBF will also improve, since it is now the MTBF of a system that has a redundant motor on standby. The costs associated with this option are shown in Table 7.

\subsection{Net Present Value (NPV) calculations}

The following information is used as input into the LCC cost profile:

- A 10-year project lifespan;

- A 12 per cent discount rate [14];

- Capital equipment cost, on the applicable scenarios; and

- $\quad$ Annual recurring costs for the maintenance and operational calculations given in the three scenarios discussed.

Table 5: Alternative 1: Do nothing

\begin{tabular}{|c|c|c|c|c|c|c|c|c|}
\hline Cost element & $\begin{array}{c}\text { MTBF } \\
- \\
\text { years }\end{array}$ & $\begin{array}{c}\text { Failures } \\
\text { or } \\
\text { activity } \\
\text { per year }\end{array}$ & $\begin{array}{l}\text { Elapsed } \\
\text { repair or } \\
\text { activity } \\
\text { - hours }\end{array}$ & $\begin{array}{c}\text { Cost for } \\
\text { labour, } \\
\text { exp, \& } \\
\text { mat }- \text { ZAR }\end{array}$ & $\begin{array}{l}\text { Part cost } \\
\text { - ZAR }\end{array}$ & $\begin{array}{c}\text { Logistics } \\
\text { cost - } \\
\text { ZAR per } \\
\text { incident }\end{array}$ & $\begin{array}{l}\text { Lost gross } \\
\text { margin - } \\
\text { ZAR }\end{array}$ & $\begin{array}{c}\text { Total } \\
\text { cost - } \\
\text { ZAR/year }\end{array}$ \\
\hline Electricity & & & & & & & & R0 \\
\hline Testing and stripping & & & & & & & & R 12066 \\
\hline $\begin{array}{l}\text { Carcass - standard } \\
\text { Work }\end{array}$ & 3 & 0,33 & 120 & R 26920 & R 5432 & R 0 & R 22058 & R 54411 \\
\hline $\begin{array}{l}\text { Carcass - additional } \\
\text { work }\end{array}$ & 4 & 0,25 & 200 & R 33650 & R 20048 & R 125 & R 16544 & R 70367 \\
\hline $\begin{array}{l}\text { Armature - standard } \\
\text { Work }\end{array}$ & 3 & 0,33 & 120 & R 26920 & R 2109 & R 0 & R 22058 & R 51087 \\
\hline $\begin{array}{ll}\text { Armature } & - \\
\text { additional work } & \end{array}$ & 4 & 0,25 & 200 & R 33650 & R 36678 & R 125 & R 16544 & R 86998 \\
\hline Field coil renewal & 3 & 0,33 & 120 & R 26920 & R 7 148 & R 0 & R 22058 & R 56126 \\
\hline Field coil repairs & 4 & 0,25 & 200 & R 33650 & R 17254 & R 125 & R 16544 & R 67573 \\
\hline $\begin{array}{l}\text { Interpole } \\
\text { renewal }\end{array}$ & 3 & 0,33 & 120 & R 26920 & R 5494 & R 0 & R 22058 & R 54472 \\
\hline Interpole coil repairs & 4 & 0,25 & 200 & R 33650 & R 15982 & R 125 & R 16544 & R 66301 \\
\hline Assembling & & & & & & & & R 14219 \\
\hline $\begin{array}{ll}\mathrm{PM} & \text { maintenance } \\
\text { visits } & \end{array}$ & & & 52 & R 34996 & & & & R 34996 \\
\hline Training costs & & & & & & & & R 0 \\
\hline TOTAL & & 2,33 & 1332 & R 277276 & $\begin{array}{r}\text { R } 110 \\
146\end{array}$ & R 500 & R 154408 & R 568615 \\
\hline
\end{tabular}

Key: exp - expendables (consumables); mat - material

Table 6: Alternative 2: Replace traction motor

\begin{tabular}{|c|c|c|c|c|c|c|c|c|}
\hline Cost element & $\begin{array}{c}\text { MTBF } \\
- \\
\text { years }\end{array}$ & $\begin{array}{c}\text { Failures } \\
\text { or } \\
\text { activity } \\
\text { per year }\end{array}$ & $\begin{array}{l}\text { Elapsed } \\
\text { repair } \\
\text { or } \\
\text { activity } \\
\text { - hours }\end{array}$ & $\begin{array}{l}\text { Cost for } \\
\text { labour, } \\
\text { exp, \& } \\
\text { mat - ZAR }\end{array}$ & $\begin{array}{l}\text { Part } \\
\text { cost - } \\
\text { ZAR }\end{array}$ & $\begin{array}{l}\text { Logistic } \\
\text { s cost - } \\
\text { ZAR per } \\
\text { incident }\end{array}$ & $\begin{array}{c}\text { Lost gross } \\
\text { margin - } \\
\text { ZAR }\end{array}$ & $\begin{array}{c}\text { Total cost } \\
- \\
\text { ZAR/year }\end{array}$ \\
\hline Electricity & & & & & & & & R0 \\
\hline Testing and stripping & & & & & & & & R 8273 \\
\hline $\begin{array}{l}\text { Carcass - standard } \\
\text { work }\end{array}$ & 5 & 0,2 & 120 & R 16152 & R 3259 & Ro & R 13235 & R 32646 \\
\hline $\begin{array}{l}\text { Carcass - additional } \\
\text { work }\end{array}$ & 6 & 0,167 & 200 & R 22433 & $\begin{array}{r}\mathrm{R} 13 \\
365\end{array}$ & R 83 & R 11029 & R 46911 \\
\hline $\begin{array}{l}\text { Armature - standard } \\
\text { work }\end{array}$ & 5 & 0,2 & 120 & R 16152 & R 1265 & Ro & R 13235 & R 30652 \\
\hline $\begin{array}{ll}\text { Armature } & - \\
\text { additional work } & \end{array}$ & 6 & 0,167 & 200 & R 22433 & $\begin{array}{r}\text { R } 24 \\
452\end{array}$ & R 83 & R 11029 & R 57998 \\
\hline
\end{tabular}




\begin{tabular}{|c|c|c|c|c|c|c|c|c|}
\hline Cost element & $\begin{array}{c}\text { MTBF } \\
- \\
\text { years }\end{array}$ & $\begin{array}{c}\text { Failures } \\
\text { or } \\
\text { activity } \\
\text { per year }\end{array}$ & $\begin{array}{l}\text { Elapsed } \\
\text { repair } \\
\text { or } \\
\text { activity } \\
\text { - hours }\end{array}$ & $\begin{array}{l}\text { Cost for } \\
\text { labour, } \\
\text { exp, \& } \\
\text { mat - ZAR }\end{array}$ & $\begin{array}{l}\text { Part } \\
\text { cost - } \\
\text { ZAR }\end{array}$ & $\begin{array}{l}\text { Logistic } \\
\text { s cost - } \\
\text { ZAR per } \\
\text { incident }\end{array}$ & $\begin{array}{c}\text { Lost gross } \\
\text { margin - } \\
\text { ZAR }\end{array}$ & $\begin{array}{c}\text { Total cost } \\
- \\
\text { ZAR/year }\end{array}$ \\
\hline Field coil renewal & 5 & 0,2 & 120 & R 16152 & R 4289 & R0 & R 13235 & R 33676 \\
\hline Field coil repairs & 6 & 0,167 & 200 & R 22433 & $\begin{array}{r}\mathrm{R} 11 \\
503\end{array}$ & R 83 & R 11029 & R 45049 \\
\hline $\begin{array}{ll}\text { Interpole } & \text { coil } \\
\text { renewal } & \\
\end{array}$ & 5 & 0,333 & 120 & R 26920 & R 5494 & R 0 & R 22058 & R 54472 \\
\hline Interpole coil repairs & 6 & 0,167 & 200 & R 22433 & $\begin{array}{r}\mathrm{R} 10 \\
655 \\
\end{array}$ & R 83 & R 11029 & R 44200 \\
\hline Assembling & & & & & & & & R 9750 \\
\hline $\begin{array}{ll}\text { Maintenance } & \text { PM } \\
\text { visits } & \end{array}$ & & & 52 & R 17498 & & & & R 17498 \\
\hline Training costs & & & & R 72000 & & & & R 72000 \\
\hline TOTAL & & 1,6 & 1332 & R 254607 & $\begin{array}{r}\mathrm{R} 74 \\
282\end{array}$ & R 333 & R 105880 & R 453127 \\
\hline
\end{tabular}

Key: exp - expendables (consumables); mat - material

Table 7: Alternative 3: Add redundant traction motor

\begin{tabular}{|c|c|c|c|c|c|c|c|c|}
\hline Cost element & $\begin{array}{l}\text { MTBF - } \\
\text { years }\end{array}$ & $\begin{array}{c}\text { Failures } \\
\text { or } \\
\text { activity } \\
\text { per } \\
\text { year } \\
\end{array}$ & $\begin{array}{l}\text { Elapsed } \\
\text { repair } \\
\text { or } \\
\text { activity } \\
\text { - hours } \\
\end{array}$ & $\begin{array}{l}\text { Cost for } \\
\text { labour, } \\
\text { exp, \& mat } \\
\text { - ZAR }\end{array}$ & $\begin{array}{l}\text { Part } \\
\text { cost - } \\
\text { ZAR }\end{array}$ & $\begin{array}{c}\text { Logistics } \\
\text { cost - } \\
\text { ZAR per } \\
\text { incident }\end{array}$ & $\begin{array}{l}\text { Lost gross } \\
\text { margin - } \\
\text { ZAR }\end{array}$ & $\begin{array}{c}\text { Total } \\
\text { cost, } \\
\text { ZAR/year }\end{array}$ \\
\hline Electricity & & & & & & & & R 0 \\
\hline $\begin{array}{l}\text { Testing and } \\
\text { stripping }\end{array}$ & & & & & & & & R 6895 \\
\hline $\begin{array}{l}\text { Carcass - standard } \\
\text { work }\end{array}$ & 6 & 0,17 & 120 & R 13460 & R 2716 & R0 & R0 & R 16176 \\
\hline $\begin{array}{l}\text { Carcass - additional } \\
\text { work }\end{array}$ & 8 & 0,125 & 200 & R 16825 & R 10024 & R 63 & R 8272 & R 35183 \\
\hline $\begin{array}{l}\text { Armature - standard } \\
\text { work }\end{array}$ & 6 & 0,167 & 120 & R 13460 & R 1054 & R 0 & R 0 & R 14514 \\
\hline $\begin{array}{l}\text { Armature - } \\
\text { additional work }\end{array}$ & 8 & 0,125 & 200 & R 16825 & R 18339 & R 63 & R 8272 & R 43499 \\
\hline Field coil renewal & 6 & 0,167 & 120 & R 13460 & R 3574 & $\mathrm{R} 0$ & R0 & R 17034 \\
\hline Field coil repairs & 8 & 0,125 & 200 & R 16825 & R 8627 & R 63 & R 8272 & R 33787 \\
\hline $\begin{array}{l}\text { Interpole coil } \\
\text { renewal }\end{array}$ & 6 & 0,33 & 120 & R 26920 & R 5494 & R 0 & R0 & R 32414 \\
\hline $\begin{array}{l}\text { Interpole coil } \\
\text { repairs }\end{array}$ & 8 & 0,125 & 200 & R 16825 & R 7991 & R 63 & R 8272 & R 33150 \\
\hline Assembling & & & & & & & & R8 125 \\
\hline $\begin{array}{l}\text { Maintenance PM } \\
\text { visits }\end{array}$ & & & 52 & R 34996 & & & & R 34996 \\
\hline Training costs & & & & & & & & R 0 \\
\hline TOTAL & & 1,33 & & R 169596 & R 57819 & R 250 & R 33088 & R 275773 \\
\hline
\end{tabular}

Key: exp - expendables (consumables); mat - material

The net present values of the three alternative scenarios were determined, and are shown in Figure 1 as a graphical comparison. Left out of these NPV calculations were the disposal and depreciation costs that could not immediately be determined, but that would likely have little influence on the cost comparisons carried out in this study. 


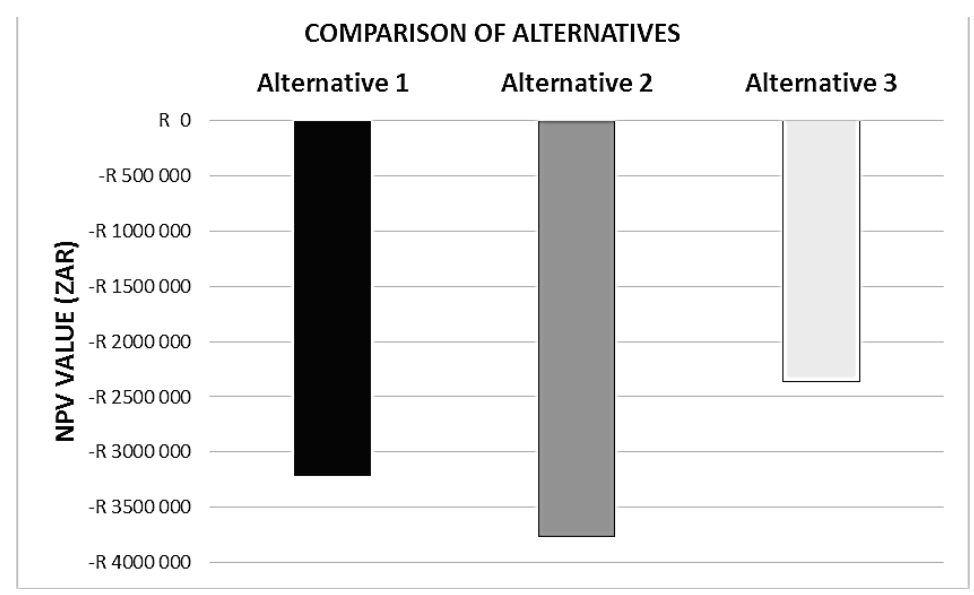

Figure 1: Comparison of alternatives in terms of NPV

\subsection{Sensitivity analysis of preferred alternative}

The inputs with the most uncertainty were identified, and are shown in Table 8 for each of the three alternatives. The table also illustrates the base values that were used to calculate the first NPV values. In order to accommodate the uncertainty that can occur, a range of possibilities between 20 per cent and +20 per cent was calculated for each of the inputs.

Table 8: Base case values and uncertainty limits for LCC input variables

\begin{tabular}{|l|l|c|c|c|}
\cline { 2 - 5 } \multicolumn{1}{c|}{} & Input description & Base value & Upper limit (+20\%) & $\begin{array}{c}\text { Lower limit } \\
\text { (-20\%) }\end{array}$ \\
\hline \multirow{2}{*}{ Alternative 1 } & Discount rate & $12 \%$ & $9,6 \%$ & $14,4 \%$ \\
& Project life & 10 & 8 & 12 \\
& Recurring costs & R 568615 & R 454 892.00 & R 682338.00 \\
\hline Alternative 2 & Capital equipment & R 1 200 000 & R 960 000 & R 1 440 000 \\
& Discount rate & $12 \%$ & $9,6 \%$ & $14,4 \%$ \\
& Project life & 10 & 8 & 12 \\
& Recurring costs & R 453 127 & R 362 502 & R 543 752 \\
\hline \multirow{2}{*}{ Alternative 3 } & Capital equipment & R 800 000 & R 640 000 & R 960 000 \\
& Discount rate & $12 \%$ & $9,6 \%$ & $14,4 \%$ \\
& Project life & 10 & 8,0 & 12,0 \\
& Recurring costs & R 275 773 & R 220 619 & R 330 928 \\
\hline
\end{tabular}

A tornado plot was then created to summarise the impact of each variable on the net present value, which is the figure of merit. The results of the three alternatives are shown in Figures 2 to 4 ; it is clear that the most critical input variable in all three alternatives is the recurring operations and maintenance costs.

\section{DISCUSSION}

The negative NPV values obtained in Section 5.3 can be attributed to the absence of expected revenues from the operation of fully functional motor coaches. The absence of these costs was due to insufficient data being available at the time of performing the calculations. Therefore, from the results of the NPV calculations given in section 5.3, it is apparent that Alternative 3 (add redundant traction motor) would be the most desirable alternative, as it has the least-negative NPV value (of R2 358 180). There is a difference of R547 467 between Alternatives 1 and 2, and of R854 622 between Alternative 3 and Alternative 1, which is the next-best option (at R3 212 802). The worst option is Alternative 2 (replace traction motor), which would result in an NPV of R3 760269 . This result was unexpected, as the generally-held perception was that replacing the traction motor would always be better than using the current one. The only logical explanation for this result would be 
due to the marginal difference in the maintenance and operations costs of the old traction motor when compared with the estimated cost of purchasing a new one.

In the sensitivity analysis, a uniform limit of $+/-20$ per cent was used for the input values. According to Seif and Rabbani [15], taking a uniform limit may be misleading, as the inputs might not all fall within that range. However, because not enough information was available for getting the exact limits, the authors decided to take this route. The results of the sensitivity analysis show that the recurring operations and maintenance costs are the most sensitive input factor, which could result in a significant change in the NPV value across all three alternatives. A change in the actual discount rate, increasing or decreasing the running life of the equipment, or a change in the estimated purchasing price of the equipment will all have a smaller effect on the NPV. It is also observed that the upper NPV limit of the recurring costs of Alternative 3 (R2 669 816) is still more favourable than all the other alternatives. It is prudent, therefore, to ensure that these recurring costs are estimated as accurately as possible to minimise the assumptions made, and thus to reduce the level of uncertainty in the model.

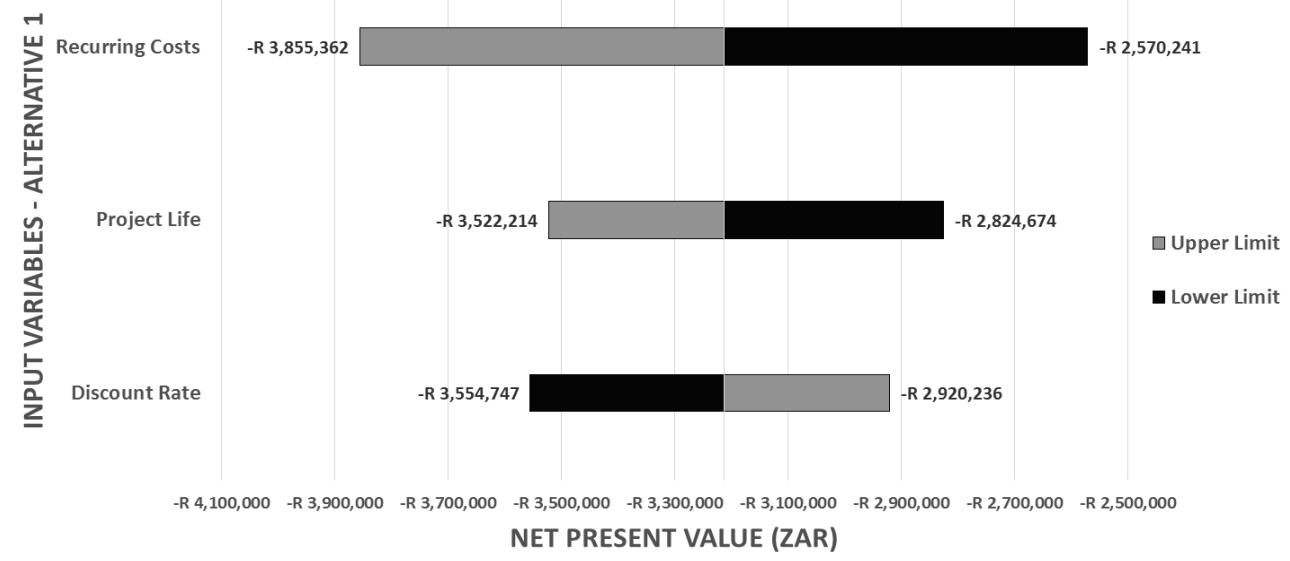

Figure 2: Tornado diagram of input variables for Alternative 1

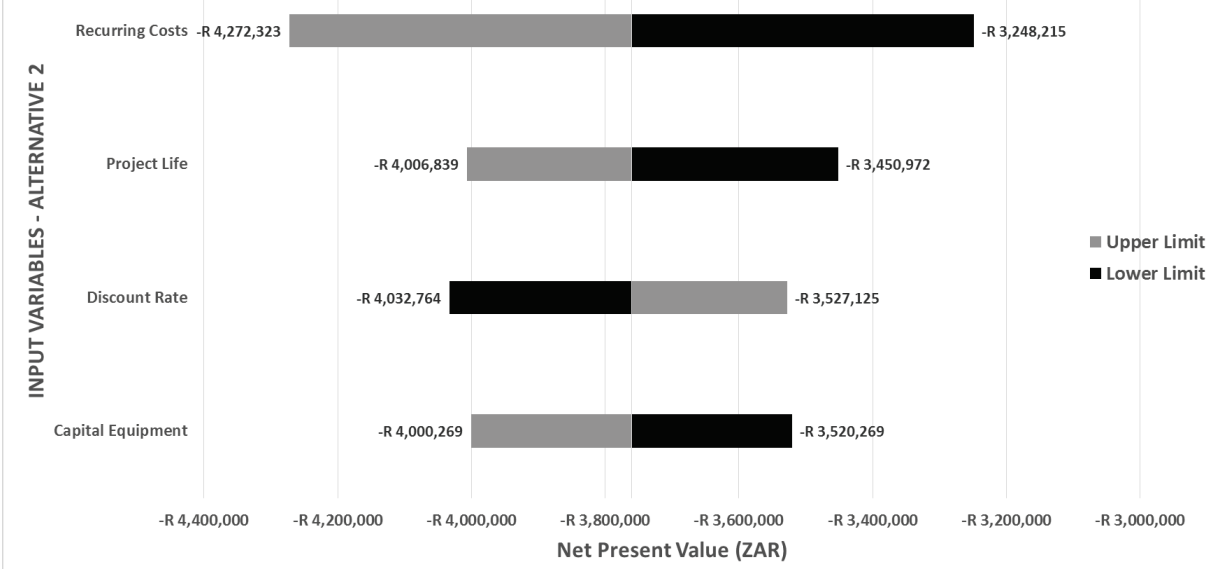

Figure 3: Tornado diagram of input variables for Alternative 2 


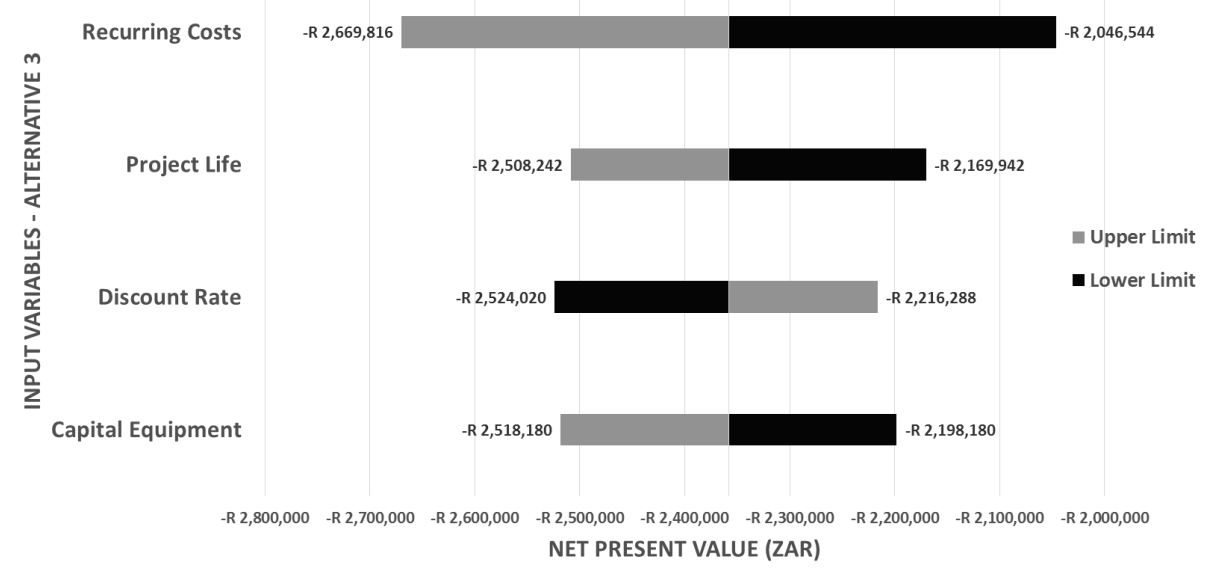

Figure 4: Tornado diagram of input variables for Alternative 3

\section{RECOMMENDATIONS}

One possible improvement to this study would be the use of stochastic models and simulations to obtain more accurate estimations of failure costs, as suggested by Seif and Rabbani [15]. In their research, the problem is modelled using mixed-integer programming with a genetic algorithm being developed to find an optimal solution. A model such as this one would be useful to address the probabilistic nature of failures and the subsequent failure costs. Other costs that can also be difficult to determine are the operations costs; these could also benefit from models that make accurate estimations of their values.

Another possible improvement would be to determine the remaining life in the current batch of 5M2A traction motors by using lifetime prediction models, such as the one developed by Herrmann, Kara and Thiede [16]. Knowing the remaining life of the component would help to develop a more accurate timeline for the LCC cost profile. This would go a long way to addressing the usual dilemma associated with maintenance - i.e., maintaining high availability but still remaining cost-effective and not spending more than necessary on spare parts and labour.

\section{CONCLUSION}

The focus of this paper has been to develop and test a life cycle costing framework for missioncritical assets, such as railway rolling stock traction motors, using their maintenance, operations, and failure history. The main assumptions made during the testing of this framework were taken through a sensitivity analysis exercise to determine the most critical factors that would affect the results of the studies undertaken. The end result was that the decision-maker is able to make informed financial decisions about which strategy to follow to obtain the best performance from components or systems in terms of reliability, availability, maintainability, and safety (RAMS).

While this study does not necessarily contribute new theory in the field of life cycle costing, it does make a contribution to applying the LCC method in a practical case study in a sector that has not been sufficiently explored. Another important contribution has been to add to the body of knowledge about innovative decision-making methods in acquiring and replacing deteriorated assets. The concept of applying LCC in RAMS is also still in its infancy, and this study helps to expand knowledge in that area. The study could be improved by including stochastic models to address the probabilistic nature of some of the costs. Another useful addition to the study would be the use of lifetime prediction models that would improve the accuracy of the calculations and assumptions made.

\section{REFERENCES}

[1] Takata, S., Kirnura, F., van Houten F.J.A.M., Westkamper. E., Shpitalni, M. \& Ceglarek, D. 2004. Maintenance: Changing role in life cycle management, CIRP Annals-Manufacturing Technology 53.2, pp 
643-655.

[2] Tendayi, T.G. \& Fourie, C.J. 2015. A life cycle costing framework for effective maintenance management in a rolling stock environment, WIT Transactions on the Built Environment, 168, pp 889-900.

[3] Blanchard, B.S. 1979. Life cycle costing: A review, Terotechnica, no, 1(1), pp 9-15.

[4] Barringer, H.P. \& Weber, D.P. 1996. Life cycle cost tutorial. Fifth international conference on process plant reliability, Houston: Gulf Publishing Company.

[5] Fuller, S. \& Petersen, S. 1996. Life-cycle costing manual for the Federal Energy Management Program, 1995 ed. NIST Handbook.

[6] Kumar, D., Chattopadhyay, G., \& Pannu, H.S. 2004. Total cost of ownership for railway assets: A case study on box wagons of Indian railways. Proceedings of the Fifth Asia-Pacific Industrial Engineering and Management Systems Conference.

[7] Jun, H.K. \& Kim, J.H. 2007. Life cycle cost modelling for railway vehicle. Electrical Machines and Systems, ICEMS. International Conference on: IEEE.

[8] Zoeteman, A. 2003. Life cycle costing applied to railway design and maintenance: Creating a dashboard for infrastructure performance planning, WIT Transactions on The Built Environment, 64.

[9] Patra, A.P. 2007. RAMS and LCC in rail track maintenance (Doctoral dissertation).Division of Operations and Maintenance Engineering, Luleå University of Technology, ISSN: 1402-1757.

[10] Puig, J.P., Basten, R. \& van Dongen, L. 2013. Investigating maintenance decisions during initial fielding of rolling stock. Procedia CIRP, 11, pp 199-203.

[11] EN50126, European Committee for Electrotechnical Standardisation. 1999. Railway applications: The specification and demonstration of reliability, availability, maintainability and safety (RAMS), ISBN: 058035694.

[12] Kim, J.W., Chung, J.D. \& Han, S.Y. 2009. Life cycle cost model for evaluating RAMS requirements for rolling stocks. Computers \& Industrial Engineering, CIE 2009. International Conference on IEEE, pp 11891191.

[13] Conradie, P. 2012. Exploring critical failure modes in the rail environment and the consequential costs of unplanned maintenance. CIE42 Proceedings, July 2012.

[14] PRASA. 2010. Annual Report 2009/2010. Available at: http://www.metrorail.co.za/pdf/PRASA_AR_2010.pdf. Accessed 9/25/2012.

[15] Seif, J. \& Rabbani, M. 2014. Component based life cycle costing in replacement decisions. Journal of Quality in Maintenance Engineering, 20(4), pp 436-452.

[16] Herrmann, C., Kara, S. \& Thiede, S. 2011. Dynamic life cycle costing based on lifetime prediction. International Journal of Sustainable Engineering, 4(3), pp 224-235. 